\title{
PIONEER BRAND ADVANTAGE WITH U.K. CONSUMERS
}

\section{Ruth Rettie, Simon Hilliar, and Frank Alpert}

\section{Ruth Rettie}

Senior Lecturer at Kingston University, Kingston Business School, Kingston University, Kingston, Surrey, KT7 2LB.

R.Rettie@Kingston.ac.uk

\section{Simon Hilliar}

MA in Marketing student at Kingston University,

Simon.Hilliar@UK.compuware.com

\section{Frank Alpert}

Professor, School of Marketing, Griffith University, Brisbane, Australia Frank.Alpert@mailbox.gu.edu.au 


\title{
PIONEER BRAND ADVANTAGE WITH U.K. CONSUMERS
}

\begin{abstract}
Pioneer advantage is derived from two sources: producer-based advantages and consumer-based advantages. The latter is relatively under-researched. This research replicates and extends Alpert and Kamins' (1995) research, which was the first to directly survey consumers. Since their research occurred only in the USA, cross-cultural replication is appropriate, (Hubbard \& Armstrong, 1994). Key results show that: consumers are able to recall a brand's pioneering status; pioneer brands generally have higher recall or retrieval than other brands including the market leader; communication of pioneer status may enhance purchase interest, both at the time of the product's introduction and years after its introduction. These results support the USA findings, and are rather more positive. However, British consumers did not agree that, if all other things were equal, they would prefer the pioneer brand. This research also shows for the first time that identification of pioneer status is related to actual purchase of that brand.
\end{abstract}

\section{Key Words}

\author{
Consumer Behaviour \\ Market Entry \\ Product Introduction \\ Branding \\ Pioneer Brands
}




\section{Introduction}

In many markets the same brands outsell their rivals for years and sometimes decades. Market share differences are especially large for brands that entered first in the product life cycle, so called "market pioneers" or "first movers" (Carpenter and Nakamoto, 1989). Examples of such pioneers include:

Wrigley's, Kleenex, Xerox (Carpenter and Nakamoto, 1989), Birds Eye, Campbell, Hallmark (Robinson and Fornell 1985), Dupont (Robinson, 1988).

Pioneer advantage potentially offers long term competitive advantage in the form of high market share (Robinson and Fornell, 1985; Urban, Carter, Gaskin and Much, 1986; Robinson, 1988; Kalyanaram and Urban, 1992; Bowman and Gatignon, 1996), barriers to entry (Porter, 1985; Robinson and Fornell, 1985; Lieberman and Montgomery, 1988), and consumer preference (Carpenter and Nakamoto, 1989; Kardes and Kalyanaram, 1992; Alpert and Kamins, 1995).

Pioneer advantage was initially explained in terms of producer-based advantages such as the creation of entry barriers, lower cost structures, etc. More recently consumer-based advantages have been identified, for example, becoming the category prototype (Carpenter and Nakamoto 1989). The latter are relatively under researched, and most studies into these psychological processes have used experimental laboratory designs with students. However, relating pioneer advantage to consumer behaviour is important because it helps to explain why pioneer advantage persists, and suggests management strategies that can exploit its potential.

In the first survey of consumers, Alpert and Kamins (1995) found evidence of awareness of, and preference for, pioneer brands among US consumers. This paper is a replication and extension of their research within the UK context.

\section{Conceptual Framework}

A brand is defined as the pioneer if it was the first brand of a new type of product. Pioneer advantage can be categorised into categories: producer-based advantages and consumer-based advantages (Golder and Tellis, 1993). Historically, research has focused on the producer-based advantages (Porter, 1985; Robinson and Fornell, 1985; Lieberman and Montgomery, 1988; Robinson, 1988).

Advantages derived from consumers are based on enhanced consumer preference, attitude, awareness, learning and memory of pioneer brands. Schmalensee (1982) researched the consumer learning process using an experimental design and students. He found that they were initially sceptical about pioneer brands, 
however, once they become convinced that the first brand in any product class performs satisfactorily, that brand becomes the standard against which subsequent brands are rationally judged.

Carpenter and Nakamoto (1989) suggest that a successful first mover can actually influence how brand attributes are valued. They also, like Schmalensee, suggest that the pioneer becomes closely associated with the product category as a whole and becomes the standard against which others are judged. Carpenter and Nakamoto argue that prototypicality and preference structure can create a source of competitive advantage for the pioneer.

Kardes and Kalyanaram's (1992) research investigated the effect that order of entry has on consumers' learning and its consequences. They found that "order of entry influences learning, which then affects attitudinal, confidence, and preference judgement in a manner that is beneficial to the pioneering brand" (page 354). In addition, using an experimental approach, they found that increased exposure to the pioneer brand through press reports or packaging labels enhanced the degree of pioneer advantage. They suggest: "managers of pioneering brands should implement promotional and channel related tactics that facilitate consumer learning." (page 355). Pioneers may also benefit from higher awareness of their advertising (Kerin, Varadarayan and Peterson, 1992), leading to greater levels of trial. Followers need to shout louder to be heard above the advertising clutter of other follower brands.

Alpert and Kamins (1995) observed that prior behavioural research focused on automatic learning effects that occur due to order of presentation. They introduced the idea of conscious consumer favorability towards a brand because of knowledge that it was the pioneer brand. Automatic learning processes are based on the act of pioneership, whereas conscious favorability is based on the fact of pioneership. In addition, the automatic learning advantages found in experiments with student subjects imply that pioneer brand names should be recalled more easily. If pioneer brands can be retrieved in memory more easily, and if consumers are aware of which brand was the pioneer, and if consumers are at all positively inclined toward brands that are pioneers (all other things being equal, i.e., under conditions of product quality ambiguity), then pioneership can to some degree provide a long lasting inimitable competitive advantage.

To investigate these issues, Alpert and Kamins (1995) were the first to conduct a large-scale survey of consumer attitudes towards actual pioneer brands. They measured consumer memory, attitude, perception, purchase intention and purchase behaviour in relation to pioneer and follower brands. Using a questionnaire mailed to the 560 members of the Arkansas Household Research Panel, they found that pioneer brands were retrieved to a higher degree than follower brands, and that consumers could remember which brands were the pioneers (supporting Kardes and Kalyanaram, 1992). In addition, they found that communication of pioneer status may increase purchase interest. 
However, their research had at least three limitations creating research needs that are addressed in this paper. 1) Replication. There are calls for more replication in marketing (Leone and Schultz, 1980; Hubbard and Armstrong, 1994). Will the findings hold up if an independent researcher attempts to implement the study design? 2) Generalizability. A unique feature of Alpert and Kamins' (1995) study was their use of real brands (as opposed to laboratory research using hypothetical products). While this enhances external validity they were only able to use eight categories, so the question arises as to whether the findings would hold across a broader range of product categories. 3) Universality. Their study surveyed real consumers (as opposed to involving students), but was conducted in only one country, the USA, so the issue of the impact of cultural context needs to be addressed by testing the research in a difference culture. They themselves recommended cross-cultural replication which they suggest "might find differing degrees of enthusiasm for pioneer brands on the basis of differing core cultural values towards change (e.g. the English are reputed to be more sceptical about change and the idea of progress.)" (page 32).

Table I summarises the major empirical pioneer advantage studies.

Take in Table I

There are related empirical studies examining other market entry effects including marketing mix strategies (Bowman and Gatignon, 1996; Venkatesh, 1997), competitor response strategy (Bowman and Gatignon, 1995; Venkatesh, 1999), stage of the product life cycle (Venkatesh (1999), Carpenter and Krishnamurti, 1999), buyer response to product quality (Bowman and Gatignon, 1996) and effects on consumers new to a market (Heilman, Bowman and Wright, 2000). A study by Chen and Arun (1999), examines the effect of a product's country-of-origin on first-mover advantage.

\section{Research Agenda}

The first five hypotheses are taken from Alpert and Kamins (1995). Hypothesis $\mathbf{H}_{\mathbf{6}}$ is new and is an extension of the original research.

\section{Pioneer Brand Recall}

If pioneership were totally irrelevant or useless to consumers, they would have little awareness of pioneership. However, if pioneer status is a distinctive attribute, and as such a source of consumer-based pioneer advantage, then consumers should recognise which brand was the pioneer. People are more likely to learn and retain what, from their perspective, is interesting and relevant. Furthermore, only if they know which brand is the pioneer can they act on it. Consistent with Alpert \& Kamins (1995), we hypothesise: $\mathbf{H}_{1}$ : Consumers will be able to correctly recall the pioneer brand in a given product category to a degree greater than chance. 


\section{Pioneer Name Retrieval}

If the laboratory experiments postulating automatic learning benefits to pioneers are correct, then a pioneer brand is more likely to be retrieved from memory in a test of unaided recall. This is a stronger test of degree of learning than the recognition test in the above hypothesis, reflective of the stronger learning inherent in the automatic learning effects argument (Carpenter and Nakamoto, 1989; Kardes and Kalyanaram, 1992). Therefore:

$\mathbf{H}_{2}$ : Consumers will retrieve pioneer brands to a degree that is significantly higher than any other brand.

\section{Pioneer Preference}

Consumers may have some degree of positive attributions and feelings toward pioneer brands. They may believe the pioneer brand is probably high quality because it takes skill to be the pioneer. They may believe it is a creditable distinction to be the pioneer or innovator. Alpert and Kamins (1995) found support for both positive attributions and positive attitude toward pioneer brands with their American sample. Therefore for replication with UK consumers we propose:

$\mathbf{H}_{3}$ : All things being equal, consumers prefer the pioneer brand in terms of purchase preference.

\section{Pioneer Communication}

What should managers do if the above hypotheses are correct? One managerially controllable action is whether to communicate pioneership in marketing communications. If pioneer status does present a consumer-based advantage, then it would be expected that directly communicating pioneership can increase purchase interest. Therefore:

$\mathbf{H}_{4}$ : Communication of pioneer status through labelling will have a positive impact on purchase interest even years after introduction.

Pioneership can have occurred long ago in an old product category. How does time of pioneership affect pioneership impact? We predict that pioneer advantage deteriorates over time (Huff and Robinson, 1994). A counter-argument or negative for pioneer brands is that of becoming perceived as somewhat archaic, somewhat old-fashioned or as falling behind in the sense of more recent brands possibly surpassing them (Alpert and Kamins, 1994). This counter-argument might increasingly mitigate the positives the older the pioneership. Hence:

$\mathbf{H}_{5}$ : Communication of pioneer status through labelling has less effect years afterwards than at the brand's introduction. 


\section{Pioneer Purchase}

If pioneer status is a consumer-based advantage then it should increase actual purchase, following the general hierarchy of effects argument, beliefs $\rightarrow$ attitude $\rightarrow$ behaviour (see, for example, review of eight cognition $\rightarrow$ affect $\rightarrow$ conation models in Crosier, 1995; or review of four hierarchy of effect models in Kotler, 1995). The original study did not pursue this managerially important link. Therefore, extending the previous research and relating awareness of pioneer status to actual consumer behaviour, the hypothesis: $\mathbf{H}_{\mathbf{6}}$ : Consumers who recall the pioneer status of a brand are more likely to have bought that brand.

\section{Methodology}

\section{Pioneer Brand Selection}

Most of the product categories and brands from Alpert and Kamins' research could not be used, either because the categories were too immature in the UK (Lite Beers, clear cola soda, wine coolers) or because there were insufficient brands within the category (disposable nappies). We applied their category selection criteria to the UK market. All brands selected had been launched within the last 20 years, so as to ensure that respondents could feasibly recall their pioneer status. In half of the categories selected the pioneer was still the brand leader, and in half it was no longer the market leader. We excluded pioneer market leaders that were so dominant as to be generic, as results there would be too easily predictable. The categories where the pioneer was the market leader were personal stereos, 2 in 1 shampoos, alcopops, and sparkling mineral water, The categories where the pioneer was not the market leader were personal computers, ice beers, compact disc layers, and fruit yoghurts. One category from the USA study was carried over (personal computers), the other seven categories are unique to the present study.

Historical issues of the marketing press confirmed the pioneer status of brands chosen. AC Nielsen, AGB Taylor Nelson, IDC and GSK Ltd provided up to date market share information for the top ten brands within each category selected.

\section{Questionnaire Design}

The questionnaire used by Alpert and Kamins was anglicised, and the categories were amended. Qualitative research was undertaken to refine the wording of the covering letter and the questionnaire. This suggested that the original questionnaire was too long for U.K. respondents (Yammarino et al (1991) found 8 studies where questionnaires over 4 pages long affected response rate). We therefore omitted the attitude questions, which we felt would not be comparable because we used different product categories. The UK questionnaire was pre-tested with a small random sample from the telephone directory. No changes were required. 


\section{Sample Design}

A list of randomly generated names and addresses was provided by NDL International Ltd, one of the UK's largest list brokers. Their database is generated through product registration documents for brown and white goods. To maximise response rate names were selected from the most recent registrations.

\section{Measures}

Pioneer Brand Recall $-\mathrm{H}_{1}$

Respondents were given a list of five brands in each of four different product categories and asked to identify the pioneer by means of a tick next to the brand that they believed to be the pioneer. To reduce guessing, a "don't know" option was included.

Pioneer Name Retrieval $-\mathrm{H}_{2}$

To test whether pioneer brands had stronger recall even when they were not brand leaders, we selected four categories where the pioneer was no longer the leader, and asked respondents to name all the brands associated with the category. Responses were analysed for the first four brands in each category.

\section{Pioneer Preference $-\mathrm{H}_{3}$}

In order to test conscious preference for pioneer brands, consumers were asked: "All things being equal (price, quality etc) would you prefer the pioneer brand?" As in the Alpert and Kamins survey a seven point combined Likert/Stapel scale was used ranging from disagree very strongly (-3) to agree very strongly (+3).

\section{Pioneer Communication $-\mathrm{H}_{4}$ and $\mathrm{H}_{5}$}

We tested communication of pioneer status by asking respondents how different descriptions ("the original", "the pioneer", etc.) would affect their interest in purchase, both at introduction, and many years later. A scale from +3 to -3 was used to measure their predicted change in purchase interest.

\section{Purchase Preference $-\mathrm{H}_{6}$}

We asked respondents to indicate which brands they had actually purchased, and compared purchase rate between those who were, and those who were not, aware of the pioneer status of those brands.

\section{Results}

The overall response rate was $74.3 \%$. This compares with Alpert and Kamins' $65.4 \%$. In total, 359 questionnaires were analysed.

\section{Pioneer Brand Recall - $\mathrm{H}_{1}$}


We hypothesised that respondents would be able to identify which brands were pioneers. Table II shows that in all four categories most people successfully identified the pioneer brand. A Chi-square test showed that in all four categories the results were significant ( $\mathrm{p}<0.01)$, confirming $\mathbf{H}_{\mathbf{1}}$.

Take in Table II.

\section{Pioneer Name Retrieval - $\mathbf{H}_{2}$}

We hypothesised that respondents would recall the pioneer brands better than the market leader and other brands in the category. This was tested by asking respondents to list all the brands that they could recall within a specified category. The categories, were all chosen because the pioneer was not the market leader. Table III shows brand retrieval levels for the main brands named in each category. In three categories the pioneer brands had the highest recall, only in the compact disc player category was the pioneer brand not recalled more often than any other brand. This high recall for the pioneer occurred even though, in each case, the pioneer is not the market leader.

In three categories, the pioneer was the most frequently recalled brand and was recalled significantly more than the brand leader $(\mathrm{p}<0.01)$. Finally in the category, compact disc players, the pioneer is the fourth most frequently recalled brand, higher than might be expected from its market position at number 8 .

Take in Table III

\section{Pioneer Preference $-\mathrm{H}_{3}$}

Take in Table IV.

It can be seen from Table IV that there is no significant preference for the pioneer brand if all things are equal. $\mathbf{H}_{3}$ is therefore not supported.

\section{Pioneer Communication $-\mathrm{H}_{4}$ and $\mathrm{H}_{5}$}

Respondents were asked "To what degree would each of the following package labels increase/decrease your interests in purchasing it?" with a response scale of "Strongly decrease" to "Strongly increase" and a midpoint of 0 as the neutral option. Table V shows the results. Both "new" and "the original" achieved a significant increase in claimed purchase interest, supporting $\mathbf{H}_{\mathbf{4}}$. Among the pioneer claims, "the original" was rated highest with the claim "the pioneer" least successful. The claims "the original" and "World's first" are deemed to enhance purchase interest, even more, years after launch, contradicting $\mathbf{H}_{5}$.

Take in Table V.

Respondents recorded the brands they had actually purchased. Table VI compares the purchase levels of the pioneer brand of those who knew it was the pioneer and of those who did not. In each case purchase was higher amongst those who recalled the brand's pioneer status. This was significant in three cases. The 
exception was the case of Perrier, which had very high purchase rate amongst both groups. Here, the difference was nearly significant $(\mathrm{p}<0.06)$. These results support hypothesis $\mathbf{H}_{6}$.

Take in Table VI.

\section{Discussion of the Results}

\section{Pioneer Brand Recall - $\mathrm{H}_{1}$ confirmed}

Consumers did recall the pioneer brand in all four categories. Consumers therefore remember pioneer status. This result suggests that pioneership is a distinctive attribute that is relevant to consumers; awareness of pioneership is one source of consumer-based advantage.

UK respondents were able to correctly identify the pioneer brand better than in the USA: 4 of 4 categories versus 3 of 5 categories. In the U.S. respondents misidentified the pioneer $38.1 \%$ of the time; in the U.K. this was lower at $17.2 \%$. This difference may be due to category choice, different market evolution, respondent demographics etc, or alternatively, it could be linked to cultural differences with conservative British consumers better able to recall pioneer brands. That is, British consumers may be more attuned to history, including brand history.

\section{Brand Name Retrieval $-\mathrm{H}_{2}$ limited support}

In three out of four categories, we found that brand name retrieval was significantly higher for the pioneer brand than the market leader. This is similar to Alpert and Kamins (1995) who found significantly higher recall in three of their five categories.

The improved brand retrieval found in both studies helps to explain pioneer advantage. Being a pioneer brand seems to create a long-term consumer-based advantage of increased consumer recall and awareness. The pioneer brand is more likely to be one of the evoked set, and therefore more likely to be bought. Generally one would expect brand awareness and retrieval to reflect market share (Ries and Trout, 1982), yet our pioneer brands had much higher retrieval than their market shares.

\section{Pioneer Preference - $\mathrm{H}_{3}$ not supported}

In this study UK consumers stated they would not be more likely to buy the pioneer brand if all other things were equal. This result contrasts with the findings of the Alpert and Kamins (1995) research (mean $=.65, \mathrm{t}=$ $8.49, \mathrm{p}<.01$ ), which found significant preference for the pioneer brand amongst their American respondent group. It is possible that the term "pioneer" has more positive connotations in the U.S. as it "taps into core American values" (Alpert and Kamins, 1995, page 36). Perhaps UK consumers do not like to directly admit to purchasing based on cues, or, being more traditional, are more sceptical of the new. Either way, the different responses suggest an interesting cultural difference. 


\section{Pioneer Communication $-\mathrm{H}_{4}$ confirmed, $\mathrm{H}_{5}$ not confirmed}

Despite UK respondents claimed indifference to the pioneer, they thought terms like "the original" and "the first" would make them more likely to purchase at launch, and even more so years after launch. This raises the possibility that if the term "the original" rather than "the pioneer" had been used to measure $\mathbf{H}_{3}$ the result might have been different (i.e., more definitive). That is, there may be subtly different cultural connotations to these words.

In line with Alpert and Kamins (1995), we found that communication of pioneer status both at introduction and years later enhanced purchase interest. In both studies the most popular term was "the original". However, while they found a decline in the impact of pioneer status over time, in the UK study the claims increased their effectiveness over time. We speculate that in comparison with Americans, British consumers are less likely to think of the passage of time as causing something to become archaic in a negative sense.

\section{Actual Purchase $-\mathbf{H}_{6}$}

We found that those who identified the pioneer brands were significantly more likely to have purchased these brands. This suggests that knowledge of the brand's pioneer status encouraged purchase. The result is important and the first link between actual consumer purchase and knowledge of pioneer status. However, the direction of causality is unclear, having purchased a brand a consumer may retain more information about it.

\section{Research Limitations}

A number of limitations apply to this research. Purchase behaviour and purchase preference are based on respondents' claims and may differ from actual behaviour. The research design precludes pioneer failures, so like other research, we are concerned here with first survivors.

The number of product categories on which the research is based was limited to eight, and the selection of categories within the criteria was subjective. The choice of categories is key because it is from these that respondents' memory of, and preference for, pioneer brands is extrapolated. In other categories, e.g., less familiar categories, consumers may not recall the pioneer brand names so readily, and may not remember which brands were the pioneers.

Respondents were based on a random selection from a list of recent registrations from purchasers of brown and white goods. The sample was biased towards females (64\% versus national statistic of 51\%) and towards the age group $35-45(50 \%$ v $26 \%)$. 
As with any cross-cultural survey research, the comparison between the two studies may be biased by different national response styles.

\section{Further Research}

Further replication is clearly desirable, using a greater number of product categories and including services where pioneer advantage may have a long term halo effect on the level of perceived service quality. There is also scope for more research to investigate when and why consumers are able to recall and identify pioneers more easily, and why those who recall pioneer status are more likely to be purchasers. In this research we explored a number of categories including both FMCG and advanced electronic products. One would expect claims like "the original" to be less advantageous in technological areas with rapid innovation than in more traditional areas.

In this research both Sony and IBM may have benefited from a spill-over or halo effect because they were pioneers in related categories. This would explain why Sony had such a high recall in the compact disc category, with a spill-over from its well-known pioneering of other categories such as the personal stereo (Walkman, Discman), and why IBM's recall in personal computers is so high. This relates to research by Karin, Kalyanaram and Howard (1996) showing that brand extensions produce greater order of entry effects than new brands. Further research into the spill-over effect could explore how pioneering one category affects related categories. Brand extensions may create the illusion that the brand is a pioneer, when it is in fact a follower. Another spill-over effect relates to world-wide pioneer status versus national pioneer status. Can a brand be recognised as the world pioneer by consumers in a country even when it is not in fact the pioneer in that country?

\section{Conclusions and Managerial Implications}

Replicating Alpert and Kamins' (1995) study, we obtained broadly similar results. Table VII compares the results of the two surveys.

Take in Table VII.

The U.K. results were more positive for pioneer brand recall ( 4 of 4 categories versus 3 of 5 categories) and pioneer name retrieval ( 3 of 4 categories versus 3 of 5 categories). However, when "all things were equal", U.K. consumers claimed indifference to the "pioneer". In both studies purchase preference at introduction was significantly increased by terms like "the original". In the U.S. being first is more important than the status of having been first; as indicated by the greater purchase interest for the pioneer at introduction than years later; the converse was true in the U.K. Taken together the two papers provide strong support for 
consumer-based pioneer advantage. Consumers have improved retrieval of pioneer brand names, they recall pioneer status, and pioneer status communication can improve purchase interest.

The recall (learning) and recognition advantages reinforce the impetus to be first to market with innovative products. The recognition advantage while surprisingly strong is still imperfect. Even though misidentification of the pioneer brand was generally much lower in the U.K. than in the U.S., in one of the categories in the U.K. study misidentification reached as high as 39\% (2 in 1 Shampoos). Misidentification is worse than a "don't know" response because it can result in pioneer advantages being conveyed to a competitor's brand that is misperceived to be the pioneer. Thus, companies with pioneer brands should consider measuring the level of misidentification and, when this is high, correct it by emphasising their true pioneership in marketing communications (e.g., featuring the tagline "the original").

The research included a direct test of managerial implications - a test of the impact of various claims to communicate first-entry status. Results show this can be communicated with significant effect with terms like "the original" or "the first"; however, in the U.K. the term "the pioneer" was seen less favourably and should not be used on packaging and advertising. The results suggest that years after product introduction it is still effective to communicate pioneership. In addition, in the U.K. study we found that if consumers recall pioneer status they are more likely to be actual purchasers.

In summary, the two surveys of representative samples using real brands contribute external validity and new insights for consumer-based pioneer brand advantage beyond the learning effects from the laboratory-style studies with student samples using hypothetical brands. The cross-cultural strength of the pioneership effect is established by the U.K. results being broadly similar to those from the U.S. However, interesting and significant differences were found between the two countries, suggesting that culture does moderate the effect of pioneership on consumers. 


\section{References}

Alpert, F.H. and Kamins, M.A. (1995) "An empirical investigation of consumer memory, attitude and perceptions towards pioneer and follower brands", Journal of Marketing, October, Vol. 59, pp. 34-45.

Alpert, F.H. and Kamins, M.A. (1994) "Consumer behavior and pioneer brand advantage: Conceptual Framework and Propositional Inventory," Journal of the Academy of Marketing Science, 22 (Summer), pp. 244-253.

Brown, C.L. and Lambkin, M. (1994) "Investigating the relationship between time in market and pioneering advantage", Management Science, October, Vol. 40 No 10, pp. 1361 - 1369.

Bowman, D. and Gatignon, H. (1995) "Determinants of competitor response time to a new product introduction",_Journal of Marketing Research, February, Vol. 32, No. 1, pp. 42 - 44.

Bowman D. and Gatignon, H. (1996) "-Order of entry as a moderator of the effect of marketing mix on marketing share", Marketing Science, Vol. 15, No. 3, pp. $222-242$.

Carpenter, G.S. and Nakamoto, K. (1989) "Consumer preference formation and pioneering advantage", Journal of Marketing Research, August, Vol. 27, pp. 285-298.

Chen, H. and Arun, P. (1999) "Product entry in international markets: the effect of country-of-origin on firstmover advantage", Journal of Product and Brand Management, Vol. 8, No. 3, pp. 218 - 231.

Crosier, K (1995), "Marketing Communications," in M.J. Baker, (Ed), Marketing: Theory and Practice, third edition, Macmillan, London.

Heilman, C., Bowman, D. and Wright G. P. (2000) "The evolution of brand preferences and choice behaviours of consumers new to a market", Journal of Marketing Research, May, Vol. 37, No. 2, pp. 139 - 155.

Hofstede, G. (1980) "Culture and Organizations", International Studies of Management \& Organization, Winter, Vol.10, pp. 15-42.

Huff, L.C. and Robinson, W.T. (1994) "Note : The impact of leadtime and years of competitive rivalry on pioneer market share advantages", Management Science, October, Vol. 40 No.10, pp. 1370-1377.

Hubbard, R. and Armstrong, J.S. (1994) "Replications and extensions in marketing: Rarely published but quite contrary", International Journal of Research in Marketing, June, Vol. 11 No. 3, pp.233-248.

Golder, P.N. and Tellis, G.J. (1993) "Pioneer advantage: Marketing logic or marketing legend?", Journal Of Marketing Research, May, Vol. 30 No. 2, pp. 158-170.

Kalyanaram, G and Urban, G.L. (1992) "Dynamic effects of the order of entry on market share, trial penetration, and repeat purchases for frequently purchased consumer goods", Marketing Science, Summer, Vol. 11 No. 3, pp. 235-250.

Kardes, F.R. and Kalyanaram, G. (1992) "Order of entry effects on consumer memory and judgement: An information integration perspective", Journal of Marketing Research, August, Vol. 29, pp. 343-357.

Kerin, R.A., Kalyanaram, G. and Howard, D.J. (1996) "Product hierarchy and brand strategy influences on the order of entry effect for consumer packaged goods", Journal of Product Innovation and Management, January, Vol.13, pp. 21-34. 
Kerin, R.A., Varadarajan, P.R. and Peterson, R.A. (1992) "First mover advantage: a synthesis, conceptual framework and research propositions", Journal of Marketing, October, Vol. 56, pp. 33-52.

Kotler, P. (1995), Marketing Management, eighth edition, Prentice-Hall, Englewood Cliffs, New Jersey.

| Lambkin, M. (1988) "-Order of entry and performance in new markets", Strategic Management Journal, Vol. 9 pp. 127-140.

Leone, R.P., and Schultz, R.L. (1995) "A study of marketing generalisations", Journal of Marketing, Vol. 44, pp. 10-18.

| Porter, M.E. (1985),_Competitive Advantage - Creating and Sustaining Superior Performance, Free Press, New York.

Ries, A and Trout, J. (1982), Positioning: The Battle for your Mind, Warner, NewYork.

Robinson, W.T. (1988) "Sources of market pioneer advantages-: The case of industrial goods industries", Journal of Marketing Research, February, Vol. 25, pp. 87-94.

Robinson, W.T. and Fornell, C. (1985) "Sources of market pioneer advantages in consumer goods industries", Journal of Marketing Research, August, Vol. 22, pp. 305-317.

Robinson, W.T., Fornell, C. and Sullivan, M. (1992), "Are market pioneers intrinsically stronger than later entrants?", Strategic Management Journal, August, Vol. 13, pp. 609-624.

Schalensee, R. (1982) "Product differentiation advantages of pioneering brands", The American Economic Review, June, pp. $349-365$.

Tellis, G and Golder, P.N. (1996) "First to market, first to fail? Real causes of market leadership", Sloan Management Review, Winter, pp. $65-75$.

Urban, G.L., Carter, T., Gaskin, S. and Mucha, Z. (1986) "Market share rewards to pioneering brands: an empirical analysis and strategic implications", Management Science, June, Vol. 32, No. 6, pp. 645-659.

Venkatesh, S. (1997) "Pioneer's marketing mix reactions to entry in different competitive game structures: theoretical analysis and empirical illustration", Marketing Science, Vol. 16, No. 3, pp. 271 - 293.

Venkatesh S., Carpenter, G.S. and Krishnamurthi L. (1998) "Late mover advantage: How innovative late entrants outsell pioneers", Journal of Marketing Research, February, Vol.35 No.1, pp. 54-70.

Venkatesh, S., Carpenter, G. S. and Krishnamurthi, L. (1999) "The advantages of entry in the growth stage of the product life cycle: an empirical analysis", Journal of Marketing Research, May, Vol. 36, No. 2, pp. $269-276$

Venkatesh, S. (1999) "New product introduction and incumbent response strategies: Their interrelationship and the role of multimarket contact", Journal of Marketing Research, August, Vol.36, No. 3, pp. 327 344.

Yammarino F.J., Skinner S.J. and Childers, T.L. (1991) "Understanding mail survey response behavior: a meta-analysis", Public Opinion Quarterly, Winter, Vol.55, pp. 613-639. 
Table I: Empirical Studies On Pioneer Advantage

\begin{tabular}{|c|c|c|}
\hline Study & Principal Findings & Methodology \\
\hline \multicolumn{3}{|c|}{ Studies of producer-based pioneer advantage } \\
\hline $\begin{array}{l}\text { Robinson \& } \\
\text { Fornell, } 1985\end{array}$ & $\begin{array}{l}\text { Market pioneers were found to have higher market shares than later } \\
\text { entrants. Market share benefits derived from direct cost savings, } \\
\text { increased marketing mix spend and consumer information advantages. }\end{array}$ & $\begin{array}{l}\text { PIMS database } \\
\text { study of } 371 \\
\text { consumer goods }\end{array}$ \\
\hline $\begin{array}{l}\text { Urban, Carter, } \\
\text { Gaskin \& } \\
\text { Mucha, } 1986\end{array}$ & $\begin{array}{l}\text { Order of entry is inversely related to market share, for a range of } \\
\text { consumer products. }\end{array}$ & $\begin{array}{l}\text { Assessor database } \\
\text { across } 24 \\
\text { categories }\end{array}$ \\
\hline $\begin{array}{l}\text { Lambkin, } \\
1988\end{array}$ & $\begin{array}{l}\text { Different strategic profiles and performance levels are found between } \\
\text { pioneers, early followers and late followers. Pioneers are found to have } \\
\text { a higher share than later entrants do. }\end{array}$ & $\begin{array}{l}\text { PIMS database } \\
\text { study of } 306 \\
\text { businesses }\end{array}$ \\
\hline $\begin{array}{l}\text { Robinson, } \\
1988\end{array}$ & $\begin{array}{l}\text { Paper shows market pioneers have higher market shares than other later } \\
\text { entrants. Increased market share derived from direct cost savings, } \\
\text { increased marketing mix spend and consumer information advantages. }\end{array}$ & $\begin{array}{l}\text { PIMS database, } \\
1209 \text { industrial } \\
\text { businesses } \\
\end{array}$ \\
\hline $\begin{array}{l}\text { Kalyanaram \& } \\
\text { Urban, } 1992\end{array}$ & $\begin{array}{l}\text { Paper researched successful later entrants and established that they } \\
\text { suffer long-term market share disadvantages. Pioneers are conversely } \\
\text { granted substantial share rewards. }\end{array}$ & $\begin{array}{l}\text { Behaviour scan } \\
\text { analysis of } 2,500 \\
\text { over } 5 \text { years }\end{array}$ \\
\hline $\begin{array}{l}\text { Robinson, } \\
\text { Fornell \& } \\
\text { Sullivan, } 1992\end{array}$ & $\begin{array}{l}\text { Paper argues that market pioneer skills and resources differ from, but } \\
\text { are not superior, to later entrants. Key factors found to be situation } \\
\text { specific factors (degree of product innovation, available distribution } \\
\text { channel etc). }\end{array}$ & $\begin{array}{l}\text { Strategic Planning } \\
\text { Institute database. } \\
171 \text { companies }\end{array}$ \\
\hline $\begin{array}{l}\text { Golder \& } \\
\text { Tellis, } 1993\end{array}$ & $\begin{array}{l}\text { Criticises research using the PIMS / assessor databases for sampling } \\
\text { bias and reliance on self-reports for pioneer classification. Finds } \\
\text { evidence of pioneering advantage but to a lesser degree than previous } \\
\text { studies. }\end{array}$ & $\begin{array}{l}\text { Historical analysis } \\
500 \text { brands/ } 50 \\
\text { product categories }\end{array}$ \\
\hline $\begin{array}{l}\text { Brown \& } \\
\text { Lambkin,1994 }\end{array}$ & $\begin{array}{l}\text { Pioneering advantage linked to length of time in the market and time } \\
\text { before second entry. Over time pioneer advantage can be dissipated. }\end{array}$ & $\begin{array}{l}\text { Assessor database } \\
\text { of } 24 \text { categories }\end{array}$ \\
\hline $\begin{array}{l}\text { Huff \& } \\
\text { Robinson, } \\
1994\end{array}$ & $\begin{array}{l}\text { Impact over time for pioneers, early followers and late followers. } \\
\text { Increased years of rivalry between pioneers and early followers reduces } \\
\text { pioneer advantage. However, later entrants continue to suffer share } \\
\text { disadvantages. }\end{array}$ & $\begin{array}{l}\text { Assessor database, } \\
34 \text { consumer } \\
\text { product categories }\end{array}$ \\
\hline $\begin{array}{l}\text { Kerin, } \\
\text { Kalyanaram \& } \\
\text { Howard, } 1996 \\
\end{array}$ & $\begin{array}{l}\text { Paper examines product hierarchy and brand strategy. Pioneer } \\
\text { advantage greater in new categories and for brand extensions. The best } \\
\text { combination is a new category pioneered by a brand extension. }\end{array}$ & $\begin{array}{l}\text { Analysis of } 2,500 \\
\text { Behaviour scan } \\
\text { panellists }\end{array}$ \\
\hline $\begin{array}{l}\text { Tellis and } \\
\text { Golder } 1996 \\
\end{array}$ & $\begin{array}{l}\text { Contrasts market pioneers with early leaders. The former found to have } \\
\text { high failure rate while the latter enjoy high share and market leadership. }\end{array}$ & Historical analysis \\
\hline $\begin{array}{l}\text { Venkatesh, et } \\
\text { al. } 1998\end{array}$ & $\begin{array}{l}\text { Innovative late movers can create sustainable advantage with faster } \\
\text { growth and repeat purchase than pioneer and less innovative late } \\
\text { movers. }\end{array}$ & $\begin{array}{l}\text { Pharmaceutical } \\
\text { sales data, } 157 \\
\text { months }\end{array}$ \\
\hline \multicolumn{3}{|c|}{ Studies of consumer-based pioneer advantage } \\
\hline $\begin{array}{l}\text { Schmalensee, } \\
1982\end{array}$ & $\begin{array}{l}\text { Paper considers pioneer advantages from perspective of consumer } \\
\text { behaviour. First entrant brands are initially viewed sceptically by } \\
\text { consumers but subsequently become the standard by which subsequent } \\
\text { brands are judged. The advantages are greater for convenience goods. }\end{array}$ & Experimental \\
\hline $\begin{array}{l}\text { Carpenter \& } \\
\text { Nakamoto, } \\
1989\end{array}$ & $\begin{array}{l}\text { Pioneer advantage can derive from consumers learning and formation } \\
\text { of preferences. Pioneers can influence how category attributes are } \\
\text { valued. The pioneer can become the "standard". . }\end{array}$ & $\begin{array}{l}48 \text { MBA students/ } \\
\text { experimental } \\
\text { approach }\end{array}$ \\
\hline $\begin{array}{l}\text { Kardes and } \\
\text { Kalyanaram, } \\
1992\end{array}$ & $\begin{array}{l}\text { Order of entry influences learning, creating a bias in preference } \\
\text { judgements towards the pioneer. }\end{array}$ & $\begin{array}{l}28 \text { MBA students, } \\
\text { experimental }\end{array}$ \\
\hline $\begin{array}{l}\text { Alpert \& } \\
\text { Kamins, } 1995\end{array}$ & $\begin{array}{l}\text { First published survey of consumer ability to recall and retrieve pioneer } \\
\text { brands, and the communication of pioneer status. Also explored the } \\
\text { relationship between pioneer brand image and ideal self-image. } \\
\text { Consumers found to have positive attitudes towards, and perceptions of, } \\
\text { pioneer brands. }\end{array}$ & $\begin{array}{l}\text { Consumer survey } \\
560 \text { households }\end{array}$ \\
\hline
\end{tabular}


Table II : Pioneer Brand Recall Levels

\begin{tabular}{|c|c|c|}
\hline \multirow{2}{*}{$\begin{array}{l}\text { Category/ } \\
\text { Brand }\end{array}$} & \multicolumn{2}{|c|}{ Brand identified as pioneer } \\
\hline & Frequency & $\%$ \\
\hline \multicolumn{3}{|l|}{ Personal Stereos } \\
\hline Sony & 250 & $69.6^{*}$ \\
\hline Bush & 35 & 9.7 \\
\hline Panasonic & 18 & 5.0 \\
\hline Alba & 8 & 2.2 \\
\hline Aiwa & 2 & 0.6 \\
\hline Don't know & 46 & 12.8 \\
\hline \multicolumn{3}{|l|}{2 in 1 Shampoo } \\
\hline Wash \& Go & 233 & $71.9^{*}$ \\
\hline Head \& Shoulders & 75 & 23.1 \\
\hline Pantene & 9 & 2.8 \\
\hline Organics & 6 & 1.9 \\
\hline Nutralia & 1 & 0.3 \\
\hline Don't know & 35 & - \\
\hline \multicolumn{3}{|l|}{ Alcopops } \\
\hline Hooch & 225 & $84.0 *$ \\
\hline Two Dogs & 28 & 10.4 \\
\hline Woody's & 8 & 3.0 \\
\hline Lemonhead & 4 & 1.5 \\
\hline Shotts & 3 & 1.1 \\
\hline Don't know & 91 & - \\
\hline \multicolumn{3}{|c|}{ Sparkling Mineral Water } \\
\hline Perrier & 280 & $84.9 *$ \\
\hline Buxton & 32 & 9.7 \\
\hline Highland Spring & 9 & 2.7 \\
\hline Strathmore & 5 & 1.5 \\
\hline Aqua Pura & 4 & 1.2 \\
\hline Don't know & 29 & - \\
\hline
\end{tabular}

Chi-square test using expected values as equal categories $* \mathrm{p}<0.01$ Shading denotes the pioneer brand.Base: 359 
Table III: Pioneer Name Retrieval

\begin{tabular}{|c|c|c|c|}
\hline \multirow{2}{*}{$\begin{array}{l}\text { Category/ } \\
\text { Brand }\end{array}$} & \multirow{2}{*}{$\begin{array}{l}\text { Market } \\
\text { Position } \\
\end{array}$} & \multicolumn{2}{|c|}{ Retrieval response level } \\
\hline & & Frequency & $\%$ \\
\hline \multicolumn{4}{|l|}{ Personal Computers } \\
\hline$\overline{\text { Apple }}$ & 8 & 175 & $24.4 *$ \\
\hline IBM & 3 & 169 & 23.5 \\
\hline Amstrad & 15 & 76 & 10.6 \\
\hline Compaq & 1 & 51 & 7.1 \\
\hline Packard Bell & 4 & 41 & 5.7 \\
\hline Other Brands (16) & - & 206 & 28.7 \\
\hline Don't know & - & 67 & - \\
\hline \multicolumn{4}{|l|}{ Ice Beer } \\
\hline Labatts & 3 & 104 & $35.9 *$ \\
\hline Fosters & 1 & 89 & 30.7 \\
\hline Budweiser & 2 & 57 & 19.7 \\
\hline Carlsberg & 4 & 18 & 6.2 \\
\hline Coors (not an ice beer) & - & 8 & 2.8 \\
\hline Other Brands (4) & - & 14 & 4.7 \\
\hline Don't know & - & 186 & - \\
\hline \multicolumn{4}{|l|}{ Compact Disc Players } \\
\hline Sony & 1 & 265 & 31.1 \\
\hline Panasonic & 6 & 126 & 14.8 \\
\hline Aiwa & - & 98 & 11.5 \\
\hline Phillips & 7 & 82 & 9.6 \\
\hline Alba & - & 48 & 5.6 \\
\hline Other Brands (11) & - & 233 & 27.4 \\
\hline Don't know & - & 53 & - \\
\hline \multicolumn{4}{|l|}{ Fruit Yoghurt } \\
\hline Ski & 2 & 270 & $36.6^{*}$ \\
\hline Muller & 1 & 143 & 19.4 \\
\hline Store Brand & - & 117 & 15.9 \\
\hline Shape & 3 & 66 & 9.0 \\
\hline St Ivel & - & 53 & 7.2 \\
\hline Other Brands (8) & - & 88 & 11.9 \\
\hline Don't know & - & 28 & - \\
\hline
\end{tabular}

2 tailed t-test of pioneer against market leader, ${ }^{*} \mathrm{p}<0.01$

NB Shading denotes the pioneer brand, italics denotes market leader 
Table IV: Analysis of Pioneer Purchase Preference

\begin{tabular}{|l|c|c|c|}
\hline Question & $\begin{array}{c}\text { Mean } \\
\text { Agreement }\end{array}$ & $\begin{array}{c}\text { Standard } \\
\text { Deviation }\end{array}$ & t value \\
\hline $\begin{array}{l}\text { All things being equal, price, } \\
\text { quality, etc, would you prefer } \\
\text { the pioneer }\end{array}$ & 0.05 & 1.74 & -0.52 \\
\hline
\end{tabular}


Table V: Pioneer Label Communication Effectiveness

\begin{tabular}{|l|c|c|c|c|c|c|}
\hline & \multicolumn{3}{|c|}{$\begin{array}{c}\text { At } \\
\text { Introduction }\end{array}$} & \multicolumn{3}{c|}{ Years } \\
Afterwards
\end{tabular}


Table VI: Relationship Between Purchase And Recall Of Pioneer Status

\begin{tabular}{|l|c|c|}
\hline & \multicolumn{2}{|c|}{ Purchase Level } \\
\hline & Recall pioneer status & Don't recall pioneer status \\
\hline Sony & $51 \% *$ & $37 \%$ \\
\hline Wash and Go & $62 \% *$ & $37 \%$ \\
\hline Hooch & $36 \% *$ & $25 \%$ \\
\hline Perrier & $83 \% *$ & $75 \% \quad{ }^{*} \mathrm{p}<0.01$ \\
\hline
\end{tabular}


Table VII: Comparison of US and UK Surveys

\begin{tabular}{|l|l|l|}
\hline \multicolumn{1}{|c|}{ US Survey } & \multicolumn{1}{|c|}{ UK Survey } \\
\hline Response Rate & \multicolumn{1}{|c|}{$65.4 \%$} & $74.3 \%$ \\
\hline $\begin{array}{l}\text { Pioneer Brand Recall } \\
\text { Pioneer brand leader }\end{array}$ & $\begin{array}{l}\text { Significantly higher in } \\
3 \text { out of 5 categories }\end{array}$ & $\begin{array}{l}\text { Significantly higher in } \\
4 \text { out of } 4 \text { categories }\end{array}$ \\
\hline $\begin{array}{l}\text { Brand Name Retrieval Vs Market Leader } \\
\text { Pioneer not brand leader }\end{array}$ & $\begin{array}{l}\text { Significantly higher } \\
\text { 3 out of 5 categories }\end{array}$ & $\begin{array}{l}\text { Significantly higher } \\
3 \text { out of } 4 \text { categories }\end{array}$ \\
\hline $\begin{array}{l}\text { 'All things being equal (price, quality } \\
\text { etc) would you prefer the pioneer brand?' }\end{array}$ & Yes: i.e. Mean $=0.65, \mathrm{t}=8.49^{*}$ & No :i.e. Mean $=0.05, \mathrm{t}=-0.52$ \\
$\begin{array}{l}\text { Pioneer Label Communication } \\
\text { "The original" at introduction }\end{array}$ & Mean $=0.75, \mathrm{t}=8.28^{*}$ & Mean $=0.54, \mathrm{t}=7.05^{*}$ \\
\hline $\begin{array}{l}\text { Pioneer Label Communication } \\
\text { "The original" years later }\end{array}$ & Mean $=0.64, \mathrm{t}=8.63^{*}$ & Mean $=0.82, \mathrm{t}=5.72^{*}$ \\
\hline
\end{tabular}


